\title{
FORMULASI DAN UJI AKTIVITAS ANTIBAKTERI KRIM EKSTRAK ETANOL HERBA SELEDRI (Apium graveolens L.) TERHADAP BAKTERI Staphylococcus aureus
}

\author{
Garry Clements $^{1)}$, Paulina V. Y. Yamlean ${ }^{1)}$, Widya Astuty Lolo ${ }^{1)}$ \\ ${ }^{1)}$ Program Studi Farmasi FMIPA UNSRAT Manado, 95115
}

\begin{abstract}
Celery herbs (Apium graveolens L.) have content flavonoid, saponin and tannin. Flavonoids have anti-inflammatory properties, antioxidants and antibacterials. This study aims to determine whether the ethanol extract of celery herbs can be formulated into cream preparations, test the quality of preparations at concentrations of 5\%, 10\% and 15\%. These methods of research are experimental laboratories by making the supply of self-sustaining herbal celery ethanol extract cream and testing the quality of the cream preparation, as well as testing of antibacterial activity was carried out using the liquid dilution method and measuring value of Minimum Inhibitory Concentration and Minimum Bactericidal Concentration using a UV-Vis Spectrophotometer. This research shows that celery herbs ethanol extract can be formulated into cream preparations, fulfilling quality test of organoleptic, scatter power, adhesion and cycling test, but that doesn't meet the requirements for homogeneity tests and $\mathrm{pH}$ tests and has antibacterial activity which not only inhibits but kills bacteria in preparations of $5 \%$ and $15 \%$
\end{abstract}

Keywords: Cream Celery herb extract, Antibacterial, Staphylococcus aureus, UV-Vis spectrophotometer

\begin{abstract}
ABSTRAK
Herba Seledri (Apium graveolens L.) memiliki kandungan flavonoid, saponin dan tannin. Flavonoid memiliki khasiat sebagai antiinflamasi, antioksidan dan antibakteri. Penelitian ini bertujuan untuk mengetahui apakah ekstrak etanol herba Seledri dapat diformulasikan menjadi sediaan krim, menguji mutu sediaan pada konsentrasi 5\%, 10\% dan 15\%. Metode penelitian ini experimental laboratorium dengan membuat Sediaan Krim Ekstrak Etanol Herba Seledri dan menguji mutu sediaan krim, serta menguji aktivitas antibakteri menggunakan metode dilusi cair dan mengukur nilai KBM dan KHM menggunakan Spektrofotometer UV-Vis. Hasil penelitian menujukkan bahwa ekstrak etanol herba Seledri dapat diformulasikan menjadi sediaan krim, memenuhi uji mutu sediaan organoleptik, daya, sebar, daya hambat dan stabilitas namun tidak memenuhi persyaratan untuk uji homogenitas dan uji $\mathrm{pH}$ serta mempunyai aktivitas antibakteri yang membunuh bakteri pada sediaan berkonsentrasi $5 \%$ dan $15 \%$.
\end{abstract}

Kata Kunci : Krim Ekstrak herba Seledri, Antibakteri, Staphylococcus aureus, Spektrofotometer UV-Vis 


\section{PENDAHULUAN}

Indonesia memiliki keanekaragaman hayati yang sangat banyak membuat negara kita menyimpan potensi untuk sumber pangan dan obat-obatan bahkan $80 \%$ dari jenis tanaman yang ada berkhasiat obat (Heriyanto, 2006). Berbagai macam penyakit dengan keluhan ringan dan berat dapat diobati dengan memanfaatkan tanaman yang terdapat di sekitar pekarangan rumah (Thomas, 1989). Salah satu tanaman obat adalah seledri (Apium graveolens L.).

Tanaman seledri merupakan (Apium graveolens L.) merupakan tanaman dari kingdom Apiaceae yang mengandung flavonoid, saponin, tannin $1 \%$, minyak atsiri $0,033 \%$, apiin, apigenin, kolin, lipase, asparagine dan vitamin (A, B dan C) (Dalimartha, 2000). Flavonoid memiliki aktivitas antiinflamasi, antioksidan, antibakteri dan sifat spasmolitik (Supriyatno dkk, 2014).

Krim merupakan salah satu bentuk sediaan topikal umumnya digunakan untuk terapi yang bersifat lokal (Nugroho, 2013). Bentuk sediaan krim lebih disukai oleh masyarakat karena mudah dibersihkan dan mudah menyebar (Ansel, 1989). Penggunaan sediaan krim juga dapat memberikan efek dingin, mengkilap dan melembabkan kulit. Sediaan krim tipe M/A dibuat dengan cara mendispersikan minyak dan air (Engelin, 2013).

Masyarakat pada umumnya menggunakan antibiotik untuk mengobati penyakit infeksi bakteri, namun penggunaan antibiotik yang tidak sesuai membuat bakteri menjadi resisten. Peningkatan resisten pada bakteri terhadap antibiotik memberikan peluang terhadap zat bioaktif dari kekayaan hayati untuk dimanfaatkan (Herawati dan Amelia, 2018). Penelitian Khildah (2011), menyatakan bahwa ekstrak herba seledri memiliki aktivitas antibakteri yang kuat terhadap bakteri Staphylococcus aureus pada konsentrasi $1 \%, 2 \%$ dan $4 \%$.

Hampir semua orang pernah mengalami infeksi bakteri Staphylococcus aureus dalam hidup karena sifat pathogen dari bakteri ini mulai dari keracunan makanan sampai infeksi kulit. Penyakit infeksi yang disebabkan bakteri Staphylococcus aureus diantaranya ialah bisul jerawat dan infeksi luka. Infeksi Staphylococcus aureus ditandai dengan adanya kerusakan jaringan yang disertai abses (Kusuma, 2009).

Berdasarkan uraian di atas maka penulis tertarik untuk membuat sediaan krim dari ekstrak daun Seledri (Apium graveolens L.).

\section{METODOLOGI PENELITIAN}

\section{Bentuk Penelitian}

Penelitian ini adalah penelitian eksperimen laboratorium dengan membuat sediaan sediaan krim ekstrak etanol daun seledri dengan konsentrasi 5\%, 10\% dan $15 \%$ serta uji aktivitas antibakteri.

\section{Waktu dan Tempat Penelitian}

Penelitian ini dilaksanakan pada bulan Juni - November 2019 di Laboratorium Farmasi Lanjutan, Program Studi Farmasi, Fakultas Matematika dan Ilmu Pengetahuan Alam, Universitas Sam Ratulangi, Manado.

\section{Alat dan Bahan}

Alat

Alat-alat yang digunakan pada penelitian ini ialah peralatan gelas (pyrex), kertas saring, toples, blender, lumpang, $\mathrm{pH}$ meter, pipet, sudip, oven, autoklaf, batang pengaduk, alat uji daya lekat dan timbangan.

\section{Bahan}

Bahan-bahan yang digunakan dalam penelitian ini ialah ekstrak daun Seledri (Apium graveolens L.), etanol 96\%, NA (Nutrient Agar), NB (Nutrient Broth), asam 
stearat, TEA, adeps lanae, parafin cair, Sagestam ${ }^{\circledR}$ (Gentamisin Sulfate), aquades dan $\mathrm{NaCl}$.

\section{Prosedur Penelitian}

Pengambilan Sampel

Sampel yang digunakan dalam penelitian ini adalah daun Seledri (Apium graveolens L.) yang diambil dari Kelurahan Karondoran, Kecamatan Ranowulu, Kota Bitung.

\section{Identifikasi Tanaman}

Identifaksi tanaman dilakukan di Laboratorium Biologi Dasar, Program Studi Biologi, Fakultas Matematika dan Ilmu Pengetahuan Alam, Universitas Sam Ratulangi Manado.

\section{Ekstraksi}

Pembuatan ekstrak dilakukan menggunakan metode maserasi. Serbuk simplisia daun seledri ditimbang sebanyak $500 \mathrm{~g}$ dan pelarut etanol $96 \%$ sebanyak 2500 $\mathrm{ml}$ dibuat perbandingan 1 : 5 , kemudian dimasukkan ke dalam wadah tertutup dan dibiarkan selama 5 hari sambil sesekali diaduk. Kemudian, disaring dengan kertas saring sehingga menghasilkan filtrat dan residu. Residu yang ada diremaserasi dengan etanol $96 \%$ sebanyak $1500 \mathrm{ml}$ dibuat perbandingan 1 : 3 dalam wadah tertutup selama 3 hari. Filtrat satu dan filtrat dua digabung dan diuapkan dengan rotary evaporator untuk memperoleh ekstrak kental. Ekstrak kental yang diperoleh dibuat dalam beberapa konsentrasi yaitu 5\%, 10\% dan $15 \%$.

\section{Formulasi}

Berikut ini merupakan Formulasi krim ekstrak etanol herba Seledri (Apium graveolens L.) $5 \%, 10 \%$ dan 15\%yang dapat dilihat pada Tabel 1.
Tabel 1. Formulasi krim ekstrak etanol herba Seledri

\begin{tabular}{|c|c|c|c|c|}
\hline \multirow{2}{*}{ Bahan } & \multirow{2}{*}{ Fungsi } & \multicolumn{3}{|c|}{ Konsentrasi } \\
\hline & & F1 & F2 & F3 \\
\hline $\begin{array}{c}\text { Ekstrak } \\
\text { Daun } \\
\text { Seledri }\end{array}$ & $\begin{array}{c}\text { Bahan } \\
\text { Aktif }\end{array}$ & $6,25 \mathrm{~g}$ & $7,5 \mathrm{~g}$ & $10 \mathrm{~g}$ \\
\hline $\begin{array}{c}\text { Asam } \\
\text { stearate }\end{array}$ & Pengemulsi & $7,25 \mathrm{~g}$ & $7,25 \mathrm{~g}$ & $7,25 \mathrm{~g}$ \\
\hline TEA & Pengemulsi & $0,75 \mathrm{~g}$ & $0,75 \mathrm{~g}$ & $0,75 \mathrm{~g}$ \\
\hline $\begin{array}{l}\text { Adeps } \\
\text { lanae }\end{array}$ & Pelumas & $1,5 \mathrm{~g}$ & $1,5 \mathrm{~g}$ & $1,5 \mathrm{~g}$ \\
\hline $\begin{array}{l}\text { Parrafin } \\
\text { Cair }\end{array}$ & Pelembab & $12,5 \mathrm{~g}$ & $12,5 \mathrm{~g}$ & $12,5 \mathrm{~g}$ \\
\hline $\begin{array}{c}\text { Aquades } \\
\text { (ad) }\end{array}$ & Pelarut & 50 & 50 & 50 \\
\hline
\end{tabular}

\section{Pembuatan Krim Ekstrak Herba Seledri}

Pembuatan sediaan krim diawali dengan membuat basis tipe krim (M/A). Basis yang dibuat terdiri dari 2 fase (fase minyak dan fase air). Fase minyak yaitu Parafin cair, Adeps lanae dan Asam Stearat dipanaskan pada suhu $70^{\circ} \mathrm{C}$. Fase air yaitu Aquades dan Trietanolamin dipanaskan juga pada suhu $70^{\circ} \mathrm{C}$. kemudian, fase minyak dipindahkan ke dalam lumpang panas diikuti dengan tambahan fase air diaduk sampai terbentuk massa krim. Langkah terakhir campurkan basis krim dengan ekstrak herba seledri dengan konsentrasi 5\%, 10\% dan 15\%.

\section{Pengujian Krim Ekstrak Herba Seledri Uji Organoleptik}

Uji organoleptik lakukan dengan menggunakan panca indra atau secara visual. Komponen yang dievaluasi meliputi bau, warna, tekstur sediaan, dan konsistensi (Elmitra, 2017).

\section{Uji Homogenitas}

Pengujian homogenitas dilakukan untuk mengetahui apakah pada saat proses pembuatan krim bahan aktif obat dengan bahan dasarnya dan bahan tambahan lain yang diperlukan tercampur secara homogen. 
Persyaratannya harus homogen sehingga krim yang dihasilkan mudah digunakan dan terdistribusi merata saat penggunaan pada kulit. Krim harus tahan terhadap gaya gesek yang timbul akibat pemindahan produk, maupun akibat aksi mekanis dari alat pengisi (Elmitra, 2017).

\section{Uji pH}

Penetapan $\mathrm{pH}$ dilakukan dengan menggunakan alat bernama $\mathrm{pH}$ meter. Karena $\mathrm{pH}$ meter hanya bekerja pada zat yang berbentuk larutan, maka krim harus dibuat dalam bentuk larutan terlebih dahulu (Elmitra, 2017).

\section{Uji Daya Sebar}

Untuk mengetahui kualitas daya sebar dari sediaan krim saat pengaplikasian pada kulit, harus dilakukan pengujian daya sebar. Sifat fisik suatu krim akan semakin baik jika daya sebar yang dihasilkan semakin besar (Voight, 1984). Persyaratan daya sebar yang baik pada sediaan krim sebesar 5-7 cm (Wasiaatmadja, 1997). Krim sebanyak 0,5 gram diletakan di antara dua plat kaca dan dibiarkan selama 1 menit. Setiap menit dinaikkan beban sebesar 50 gram hingga 250 gram, lalu diukur diameter yang dihasilkan (lakukan sebelum dan sesudah uji stabilitas).

\section{Uji Daya Lekat}

Pengujian daya lekat pada sediaan krim bertujuan untuk mengetahui lamanya kontak krim dengan kulit hingga efek terapi yang diharapkan tercapai (Voight, 1984). Syarat krim yang baik memiliki daya lekat lebih dari 4 detik (Wasiaatmadja, 1997). Krim sebanyak 0,5 gram diletakkan pada plat kaca. Kedua plat kaca ditempelkan hingga menyatu, diberi beban sebesar 250 gram selama 5 menit, kemudian dilepaskan. Setelah itu diberi beban pelepasan sebasar 80 gram. Waktu dicatat hingga kedua plat kaca terlepas (lakukan sebelum dan sesudah uji stabilitas).

\section{Cycling Test}

Sediaam krim disimpan pada suhu $4{ }^{\circ} \mathrm{C}$ selama 24 jam, setelah itu disimpan pada suhu $40^{\circ} \mathrm{C}$ selama 24 jam, dilakukan sebanyak 6 siklus. Diamati perubahan fisik dari krim dengan pengamatan organoleptic, homogenitas, $\mathrm{pH}$, daya sebar dan daya lekat (Dewi, 2010).

\section{Uji Aktivitas Antibakteri}

Metode yang digunakan yaitu metode dilusi cair Kirby dan Baueryang dimodifikasi (Lennette, dkk., 1991) menggunakan media cair Nutrient Broth (NB) dengan pengukuran absorbansi menggunakan Spektrofotometer UV-Vis sebelum dan sesudah inkubasi agar dapat melihat pertumbuhan bakteri.

\section{HASIL DAN PEMBAHASAN}

Hasil Pengamatan uji organoleptik dapat dilihat pada Tabel 2.

Tabel 2. Hasil Pengujian Organoleptik krim ekstrak etanol herba Seledri (Apium graveolens $\mathrm{L}$.)

\begin{tabular}{cccc}
\hline Sediaan & \multicolumn{3}{c}{ Sebelum Penyimpanan } \\
\cline { 2 - 4 } $\begin{array}{c}\text { Konsentr } \\
\text { asi) }\end{array}$ & Aroma & Warna & bentuk \\
\hline $5 \%$ & $\begin{array}{c}\text { Khas Herba } \\
\text { Seledri }\end{array}$ & Hijau & $\begin{array}{c}\text { Semi } \\
\text { padat }\end{array}$ \\
& $\begin{array}{c}\text { Khas Herba } \\
\text { Seledri }\end{array}$ & Hijau & $\begin{array}{c}\text { Semi } \\
\text { padat }\end{array}$ \\
$10 \%$ & $\begin{array}{c}\text { Semi } \\
\text { Khas Herba } \\
\text { Seledri }\end{array}$ & Hijau & $\begin{array}{c}\text { pedat } \\
\text { pad }\end{array}$ \\
\hline
\end{tabular}

Pengamatan organoleptik yang meliputi warna, aroma dan bentuk menunjukkan bahwa sediaan yang dihasilkan berwarna hijau, dengan aroma khas dari ekstrak etanol herba seledri dan bentuk semi padat. Setelah dilakukan penyimpanan pada suhu $4^{\circ} \mathrm{C}$ dan $40^{\circ} \mathrm{C}$, sediaan tidak mengalami 
perubahan pada warna, aroma dan bentuk, hal ini menunjukkan bahwa sediaan krim ekstrak etanol herba seledri memiliki stabilitas yang baik dalam proses penyimpanan. Serta untuk basis krim sebelum dan sesudah penyimpanan tidak mengalami perubahan, aroma khas adeps lanae, warna putih dan bentuk semi padat.

Tabel 3. Hasil Pengujian Homogenitas krim ekstrak etanol herba Seledri (Apium graveolens $\mathrm{L}$.)

\begin{tabular}{|c|c|c|}
\hline \multirow{2}{*}{$\begin{array}{c}\text { Sediaan } \\
\text { (Konsentrasi) }\end{array}$} & $\begin{array}{c}\text { Sebelum } \\
\text { Cycling Test }\end{array}$ & $\begin{array}{c}\text { Sesudah } \\
\text { Cycling Test }\end{array}$ \\
\hline & & $\begin{array}{l}\text { Siklus } 1 \text { - } \\
\text { Siklus } 6\end{array}$ \\
\hline $5 \%$ & Tidak Homogen & $\begin{array}{c}\text { Tidak } \\
\text { Homogen }\end{array}$ \\
\hline $10 \%$ & Tidak Homogen & $\begin{array}{c}\text { Tidak } \\
\text { Homogen }\end{array}$ \\
\hline $15 \%$ & Tidak Homogen & $\begin{array}{c}\text { Tidak } \\
\text { Homogen }\end{array}$ \\
\hline Basis & Homogen & Homogen \\
\hline
\end{tabular}

Pengujian homogenitas ini bertujuan untuk mngetahui bahwa bahan-bahan dalam pembuatan sediaan krim tercampur sehingga tidak terlihat butiran di dalamnya. Hasil dari pengujian menunjukkan bahwa pada krim yang dicampurkan dengan ekstrak kental herba seledri, terdapat butiran-butiran kecil dari ekstrak herba seledri. Ini menyatakan bahwa pada krim dengan campuran ekstrak kental herba seledri tidak homogen. Hal ini tidak sesuai dengan persyaratan homogenitas krim, yaitu krim dikatakan homogen jika terdapat persamaan warna yang merata dan tidak ditemukan partikel pada krim (Ida dan Noer, 2012). Sedangkan, untuk basis dari krim dinyatakan homogen karena tidak ada susunan butiran yang kasar.
Tabel 4. Hasil Pengujian pH krim ekstrak etanol herba Seledri (Apium graveolens $\mathrm{L}$.)

\begin{tabular}{ccc}
\hline $\begin{array}{c}\text { Sediaan } \\
\text { (Konsentrasi) }\end{array}$ & $\begin{array}{c}\text { Sebelum } \\
\text { Cycling Test } \\
\text { pH }\end{array}$ & $\begin{array}{c}\text { Sesudah } \\
\text { Cycling } \\
\text { Test } \\
\text { pH }\end{array}$ \\
\hline $5 \%$ & 8,7 & 8,4 \\
$10 \%$ & 7 & 7,4 \\
$15 \%$ & 7,4 & 7,5 \\
Basis & 8,6 & 8,7 \\
\hline
\end{tabular}

Pengkuran $\mathrm{pH}$ pada sediaan krim ekstrak etanol herba seledri dilakukan untuk mengetahui kadar asam basa dari sediaan. Hasil dari pengukuran $\mathrm{pH}$ sebelum penyimpanan 8,7 untuk krim dengan konsentrasi 5\%, pH 7 untuk krim dengan konsentrasi $10 \%, \mathrm{pH} 7,4$ untuk krim dengan konsentrasi $15 \%$ dan $\mathrm{pH}$ 8,6 untuk basis krim. Sedangkan, $\mathrm{pH}$ sesudah penyimpanan 8,4 untuk krim dengan konsentrasi 5\%, pH 7,4 untuk krim dengan konsentrasi 10\%, $\mathrm{pH} 7,5$ untuk krim dengan konsentrasi $15 \%$ dan $\mathrm{pH}$ 8,7 untuk basis krim. Dengan hasil yang diperoleh menunjukkan bahwa $\mathrm{pH}$ dari sediaan krim ekstrak etanol herba seledri dapat mengiritasi kulit dikerenakan nilai $\mathrm{pH}$ yang didapat tidak sesuai dengan persyaratan, yaitu pH 4,5-6,5 (Tranggono dan Latifa, 2007).

Tabel 5. Hasil Pengujian Daya Sebar krim ekstrak etanol herba Seledri (Apium graveolens L.)

\begin{tabular}{cccccccccc}
\hline & \multicolumn{1}{c}{ Siklus } \\
\cline { 2 - 8 } $\begin{array}{c}\text { Kons } \\
\text { entra } \\
\text { si }\end{array}$ & $\mathbf{0}$ & $\mathbf{1}$ & $\mathbf{2}$ & $\mathbf{3}$ & $\mathbf{4}$ & $\mathbf{5}$ & $\mathbf{6}$ & $\begin{array}{c}\text { rata } \\
\text { rata }\end{array}$ \\
\hline $5 \%$ & 6,0 & 5,9 & 6,5 & 6,8 & 6,8 & 6,5 & 6,1 & 6,41 \\
$10 \%$ & 5 & 5 & 5,3 & 4,8 & 5,1 & 5,8 & 5,7 & 5,26 \\
$15 \%$ & 5,3 & 5,3 & 6,1 & 6,1 & 6,1 & 6,2 & 6,1 & 5,91 \\
Basis & 7,1 & 6,9 & 7,4 & 5,4 & 7,4 & 7,6 & 6,8 & 6,96 \\
\hline
\end{tabular}

Pengujian daya sebar dilakukan untuk mengamati kemampuan dari suatu sediaan krim menyebar pada permukaan kulit saat pemakaian. Hasil yang didapatkan dari 
pengujian daya sebar menunjukkan bahwa sediaan krim ekstrak etanol herba seledri sebelum dan sesudah penyimpanan $4^{\circ} \mathrm{C}$ dan $40^{\circ} \mathrm{C}$ memiliki daya sebar yang baik terhadap kulit, dengan rata-rata $6,41 \mathrm{~cm}$ pada krim konsentrasi 5\%; 5,26 $\mathrm{cm}$ pada krim konsentrasi $10 \%$; $5,91 \mathrm{~cm}$ pada krim konsentrasi $15 \%$ dan $6,96 \mathrm{~cm}$ pada basis krim. Hal ini menunjukkan bahwa krim yang dibuat memenuhi persyaratan daya sebar yang baik, yaitu 5-7 cm (Wasiaatmadja, 1997).

Tabel 6. Hasil Pengujian Daya Lekat krim ekstrak etanol herba Seledri (Apium graveolens L.)

\begin{tabular}{|c|c|c|c|c|c|c|c|c|}
\hline \multirow[b]{2}{*}{$\begin{array}{l}\text { Kon } \\
\text { sent } \\
\text { rasi }\end{array}$} & \multicolumn{8}{|c|}{ Siklus } \\
\hline & $\mathbf{0}$ & 1 & 2 & 3 & 4 & 5 & 6 & $\begin{array}{c}\text { Ra } \\
\text { ta- } \\
\text { rat } \\
\text { a }\end{array}$ \\
\hline $5 \%$ & $\begin{array}{c}95,4 \\
5\end{array}$ & $\begin{array}{c}98.1 \\
5\end{array}$ & $\begin{array}{c}96,0 \\
1\end{array}$ & $\begin{array}{c}98,5 \\
6\end{array}$ & $\begin{array}{c}94, \\
3\end{array}$ & $\begin{array}{c}99, \\
1\end{array}$ & $\begin{array}{c}10 \\
4,6 \\
4\end{array}$ & $\begin{array}{c}98,1 \\
5\end{array}$ \\
\hline $\begin{array}{c}10 \\
\%\end{array}$ & $\begin{array}{c}129 \\
83\end{array}$ & $\begin{array}{c}177 \\
37\end{array}$ & $\begin{array}{c}163 \\
67\end{array}$ & $\begin{array}{c}170 \\
34\end{array}$ & $\begin{array}{c}15 \\
7,6 \\
5\end{array}$ & $\begin{array}{c}15 \\
5,2 \\
4\end{array}$ & $\begin{array}{c}16 \\
1,2 \\
9\end{array}$ & $\begin{array}{c}159 \\
34\end{array}$ \\
\hline $\begin{array}{l}15 \\
\%\end{array}$ & $\begin{array}{c}190 \\
82\end{array}$ & $\begin{array}{c}181 \\
62\end{array}$ & $\begin{array}{c}160 \\
35\end{array}$ & $\begin{array}{c}104 \\
76\end{array}$ & $\begin{array}{l}70 \\
12\end{array}$ & $\begin{array}{l}46, \\
35\end{array}$ & $\begin{array}{r}40 \\
14\end{array}$ & $\begin{array}{c}113, \\
45\end{array}$ \\
\hline $\begin{array}{c}\text { Basi } \\
\text { s }\end{array}$ & $\begin{array}{c}286 \\
09\end{array}$ & $\begin{array}{c}260 \\
03\end{array}$ & $\begin{array}{c}170 \\
55\end{array}$ & 5,41 & $\begin{array}{l}18 \\
13\end{array}$ & $\begin{array}{l}26, \\
58\end{array}$ & $\begin{array}{l}31, \\
32\end{array}$ & $\begin{array}{c}114, \\
02\end{array}$ \\
\hline
\end{tabular}

Pengujian daya lekat dilakukan agar dapat mengukur ketahanan atau kemampuan sediaan krim untuk melekat pada kulit saat pengaplikasian. Hasil yang didapat sebelum penyimpanan untuk krim dengan konsentrasi 5\% adalah 1 menit 35,45 detik, konsentrasi $10 \%$ adalah 2 menit 09,83 detik, konsentrasi $15 \%$ adalah 3 menit 10,82 detik dan untuk basis krim adalah 4 menit 46,09 detik. Setelah penyimpanan $4{ }^{\circ} \mathrm{C}$ dan $40^{\circ} \mathrm{C}$ untuk krim dengan konsentrasi 5\% adalah 1 menit 44,64 detik, konsentrasi $10 \%$ adalah 2 menit 41,29 detik, konsentrasi $15 \%$ adalah 40,14 detik dan untuk basis krim adalah 31,32 detik. Hasil ini menunjukkan bahwa krim sesuai dengan persyaratan karena semakin lama krim melekat pada kulit maka akan semakin banyak zat aktif dari sampel ekstrak etanol herba seledri yang diabsorbsi dan akan lebih optimal, daya lekat krim yang baik yaitu lebih dari 4 detik (Wasiaatmadja, 1997).

Pengujian aktivitas antibakteri sediaan krim ekstrak herba seledri terhadap Staphylococcus aureus dilakukan dengan 3 kali pengulangan untuk setiap konsentrasi serta kontrol positif dan kontrol negatif. Hasil dari pengujian ini didapat dari pembacaan spektrofotometer UV-Vis pada panjang gelombang 400-700 nm dengan point pick 672,60 nm dan Nutrient Broth sebagai media, menunjukkan adanya aktivitas daya hambat dan daya bunuh. Untuk konsentrasi 5\% didapatkan hasil -0,766; konsentrasi $10 \%$ didapatkan hasil 0,885 ; konsentrasi $15 \%$ didapatkan hasil -0,511; kontrol positif (Sagestam $\left.{ }^{\circledR}\right)$ didapatkan hasil -0,174 dan kontrol negatif (basis krim) didapatkan hasil 0,036 . Daya bunuh terdapat pada konsentrasi $5 \%$ dan $15 \%$ yang ditunjukkan dengan berkurangnya nilai absorbansi setelah dilakukan inkubasi 1x24 jam. Semakin kecil nilai absorbansi maka akan semakin besar daya hambat terhadap bakteri. Nilai minus pada absorbansi menunjukkan bahwa sampel yang dicampur dengan bakteri tidak hanya memiliki daya hambat yang kuat tetapi memiliki daya bunuh terhadap bakteri.

Tabel 7. Hasil Pengujian Aktivitas Antibakteri krim ekstrak etanol herba Seledri (Apium graveolens $\mathrm{L}$.)

\begin{tabular}{lccc}
\hline Sediaan & $\begin{array}{c}\text { Sebelum } \\
\text { Inkubasi } \\
(\mathbf{n m})\end{array}$ & $\begin{array}{c}\text { Sesudah } \\
\text { Inkubasi } \\
(\mathbf{n m})\end{array}$ & $\begin{array}{c}\text { Hasil } \\
(\mathbf{n m})\end{array}$ \\
\hline $\begin{array}{l}\text { Konsentrasi } \\
\text { 5\% }\end{array}$ & 3,296 & 2,53 & $-0,766$ \\
$\begin{array}{l}\text { Konsentrasi } \\
10 \%\end{array}$ & 1,297 & 2,182 & 0,885 \\
$\begin{array}{l}\text { Konsentrasi } \\
15 \%\end{array}$ & 2,826 & 2,315 & $-0,511$ \\
Kontrol + & 2,406 & 2,232 & $-0,174$ \\
Kontrol - & 2,495 & 2,531 & 0,036 \\
\hline
\end{tabular}




\section{KESIMPULAN}

Berdasarkan hasil penelitian dapat disimpulkan bahwa :

1. Ekstrak etanol herba seledri dapat diformulasikan menjadi sediaan krim dengan konsentrasi 5\%, 10\% dan $15 \%$.

2. Sediaan krim ekstrak etanol herba seledri memenuhi standar mutu sediaan untuk uji organoleptik, uji daya sebar, uji daya lekat dan uji stabilitas. Tetapi tidak memenuhi standar mutu untuk uji $\mathrm{pH}$ karena sediaan yang dibuat tidak sesuai pedoman (dapat mengiritasi kulit) serta tidak memenuhi standar mutu untuk uji homogenitas karena masih terdapat butiran ekstrak kental pada sediaan krim.

3. Sediaan krim ekstrak etanol herba seledri memiliki aktivitas antibakteri terhadap Staphylococcus aureus bahkan memiliki daya bunuh pada sediaan dengan konsentrasi $5 \%$ dan $15 \%$.

\section{SARAN}

Perlu dilakukan penelitian lebih lanjut untuk uji aktivitas antibakteri dengan metode difusi dan evaluasi fisik yang belum dilakukan yaitu uji viskositas dan uji iritasi.

\section{DAFTAR PUSTAKA}

Ansel H.C. 1989. Pengantar Bentuk Sediaan

Farmasi. IU Press. Jakarta.

Dalimartha, S. 2000 Atlas Tumbuhan Obat Indonesia Jilid 2. Trubus Agriwidya. Jakarta.

Dewi R.K. 2010. Optimasi Formulasi Mikroemulsi Sediaan Hormon Testosteron Undekanoa. Universitas Negeri Islam Negeri Syarif Hidayatullah. Jakarta.

Engelin. 2013. Optimasi Krim Sarang Burung Walet Putih Tipe M/A Dengan Variasi Emulgator Sebagai Pencerah Kulit Menggunakan Simplex Lattice Design. Fakultas Kedokteran, Universitas Tanjungpura Pontianak.
Elmitra. 2017. Buku Dasar-dasar Farmasetika dan Sediaan Semi Solid. Penerbit Deepublish. Yogyakarta.

Herawati E., Amelia., T. R. N. 2018. Potensi Bahan Herbal Ekstrak Etanol Daun Mengkudu Asal Desa Wajar Lor, Tulungagung, Jawa Timur Terhadap Bakteri Penyebab Jerawat. Jurnal Kesehatan. 2(2).

Heriyanto, N. M., 2006, Keanekaragaman Jenis Pohon Yang berpotensi Obat di Taman Nasional Meru Betiri, Jawa Timur, Badan Penelitian dan Pengembangan Kehutanan. Departemen Kehutanan, Bogor.

Ida, N., Noer, S.F. 2012 Uji Stabilitas Fisik Gel Ekstrak Lidah Buaya (Aloe Vera L.). Majalah Farmasi dan Farmakologi. 16 (2): 79-84

Khilda, K., Ihwan. 2011. Uji Efek Antibakteri Ekstrak Etanol Herba Seledri (Apium graveolens Linn.) Terhadap Escherichia coli dan Staphylococcus aureus dan Analisis KLT Bioautografi, Jurnal Biocelebes. Universitas Tadulako. Palu. 5:13-21.

Kusuma, S. A. F. 2009. Staphylococcus aureus. Makalah Farmasi Unpad. Bandung.

Lennette. 1991. Manual Clinical Microbiology (5 $5^{\text {th }}$ Edition). American Siciaty for Microbiology. Washington DC.

Nugroho, Akhmad K. 2013. Sediaan Transdermal: Solusi Masalah Terapi Obat. Pustaka Pelajar. Yogyakarta.

Tranggono, R.I., Latifah, F. 2007. Buku Pegangan Ilmu Pengetahuan Kosmetik. Gramedia Pustaka Utama. Jakarta.

Voigt, R. 1984. Buku Pelajaran Teknologi Farmasi edisi kelima, diterjemahkan oleh Soewandhi, S.M. Gadjah Mada University Press Yogyakarta.

Wasitaatmadja, S.M. 1997. Penuntun Ilmu Kosmetik Medik. Penerbit Universitas Indonesia. Jakarta. 